\title{
Discretionary-Accruals Models and Audit Qualifications
}

\author{
Eli Bartov \\ Leonard N. Stern School of Business \\ New York University \\ 40 W. 4th St., Suite 423 \\ New York, NY 10012 \\ EMAIL: ebartov@stern.nyu.edu
}

\author{
Ferdinand A. Gul \\ and \\ Judy S.L. Tsui \\ Department of Accountancy \\ City University of Hong Kong \\ 83 Tat Chee Avenue \\ Kowloon Tong \\ Hong Kong
}

January 2000

First draft: October 1998

This paper has been presented at Penn State, the University of Rochester, and the Ninth Annual Conference on Financial Economics and Accounting. 


\section{Discretionary-Accruals Models and Audit Qualifications}

\section{Introduction}

A major strand of the earnings management literature examines managers' use of discretionary accruals to shift reported income among fiscal periods. Such an examination entails specification of a model to estimate discretionary accruals. The models range from the simple, in which total accruals are used as a measure of discretionary accruals to the relatively sophisticated (regression), which decompose accruals into discretionary and nondiscretionary components. The most popular six models are the DeAngelo (1986) Model, Healy (1985) Model, the Jones (1991) Model, the Modified Jones Model (Dechow, Sloan, and Sweeney 1995), the Industry Model (Dechow, Sloan, and Sweeney 1995), and the Cross-Sectional Jones Model (DeFond and Jiambalvo 1994).

Dechow, Sloan, and Sweeney (1995) evaluated the relative performance of five of these models in detecting earnings management by comparing the specification and power of commonly used tests across discretionary accruals generated by the models. They evaluated the specification of the test statistics by examining the frequency with which the statistics generate type I errors and the power of the tests by examining the frequency with which the statistics generate type II errors. Using various samples and assumptions, they demonstrated that all models appear well specified for random samples, generate tests of low power for earnings management, and reject the null hypothesis of no earnings management at rates exceeding the specified test-levels when applied to samples of firms with extreme financial performance. Additionally, they showed that the Modified Jones Model provides the most powerful test of earnings management. 
Prior studies have also focused on evaluating the ability of discretionary-accruals models to segregate earnings into discretionary and nondiscretionary components by examining their time-series properties (Hansen 1996). Other studies (e.g., Chaney, Jeter, and Lewis 1995, and Subramanyam 1996) have used the association between stock returns, and discretionary accruals and nondiscretionary earnings to study the valuation relevance of discretionary accruals. These studies concluded that managers use discretionary accruals to convey their private information to investors.

Guay, Kothari, and Watts (1996) pointed out that comparisons of discretionary-accruals models in Dechow, Sloan, and Sweeney (1995) critically hinge on such important (implicit) assumptions as the behavior of earnings absent discretion and how management exercises discretion over accruals conditional on nondiscretionary earnings. Evaluations of discretionaryaccruals models using stock returns depend, additionally, on assumptions about the relation between accounting numbers and stock prices (e.g., market efficiency with respect to earnings information, and stock prices lead earnings). Guay, Kothari, and Watts also pointed out that attempts to increase statistical power by using non-random samples (e.g., firms with extreme financial performance, Dechow, Sloan, and Sweeney 1995) cloud the findings, as they increase the likelihood that correlated omitted variables cause the results.

In an effort to improve on the methodology of this prior research for evaluating discretionary-accruals models, Guay, Kothari, and Watts first made predictions on the basis of explicit assumptions regarding the relation between stock returns, and discretionary accruals and nondiscretionary earnings. Using a random sample, they then investigated whether the various accrual-based models produce discretionary accruals and nondiscretionary earnings that conform to their predictions. Their findings cast doubts on the ability of the models to separate accruals 
into discretionary and nondiscretionary components. Healy (1996), however, pointed out that Guay, Kothari, and Watts' study relies on strong assumptions such as strong-form stock market efficiency, and that its tests examine the aggregate relation between stock returns, discretionary accruals, and nondiscretionary earnings, rather than relations for a specific sample where earnings management is expected. Thus, whether these discretionary-accruals models are able to separate accruals into discretionary and nondiscretionary components and thereby detect earnings management is still an open empirical question.

The primary goal of this study is to evaluate empirically the ability of the cross-sectional version of two discretionary-accruals model, the Cross-Sectional Jones Model and the CrossSectional Modified Jones Model, to detect earnings management vis-à-vis their time series counterparts. We are motivated to undertake this evaluation because the two cross-sectional models have not been evaluated by prior research, and because, ex ante, it is unclear which type of model dominates as each type relies on a different set of assumptions and it is an empirical question which set is more descriptively valid. We note that the cross-sectional models have a number of advantages over their time-series counterparts. Specifically, using a cross-sectional rather than a time-series model in estimating discretionary accruals (e.g., the Cross-Sectional Modified Jones Model rather than the Modified Jones Model) should result in a larger sample size that is less subject to a survivorship bias. Moreover, cross-sectional models also allow investigation of firms with a shorter history than required for time-series models, e.g., new startups engaging in initial public offerings.

To allow comparisons between the ability of these two cross-sectional models and the five models examined by prior research to detect earnings management, we also reexamine these five models using our new sample and new research method that controls potential research 
confounds. This reexamination will also enable us to assess the robustness of Dechow, Sloan, and Sweeney's (1995) findings, which seems warranted in light of the criticisms raised in the Guay, Kothari, and Watts' (1996) study.

One aspect of our method for evaluating the relative performance of the various models concerns maximizing statistical power by examining the association between discretionary accruals they generate and the likelihood of receiving an audit qualification. The intuition underlying this approach is straightforward. It follows from prior earnings management studies (see, e.g., Healy 1985, DeAngelo 1986, and Jones 1991) that high discretionary accruals indicate earnings manipulations. Thus, if discretionary accruals indicate earnings manipulations, they should be associated with the likelihood of auditors' issuing qualified audit reports.

A distinguishing feature of our research method is our simultaneous effort to maximize power (by carefully selecting a sample where earnings management is expected) while minimizing potential biases arising from using a non-random sample that may lead to erroneous inferences (by adding controls for potential research confounds). For example, Dechow, Sloan, and Sweeney $(1995,208-209)$ reported that for firms experiencing extreme financial performance, the discretionary-accruals models they evaluate are unable to completely extract the low (high) non-discretionary accruals associated with the low (high) earnings performance. We thus evaluate the association between discretionary accruals and audit qualifications after controlling for earnings performance.

Chi-square tests and univariate logistic-regression tests of 166 distinct firms with qualified audit opinions and 166 matched-pair firms with clean reports show that all models, except the DeAngelo Model, are successful in detecting earnings management. More specifically, the chi-square tests show a relatively high number of firms with a clean opinion in 
the lowest discretionary accruals quintile and a relatively high number of firms with a qualified report in the highest discretionary accruals quintile. The univariate logistic regressions also show a significant relation between discretionary accruals and the likelihood of receiving qualified reports. Thus, like Dechow, Sloan, and Sweeney (1995), using univariate tests that do not control for potential research confounds, we provide evidence suggesting that the Jones Model, the Modified Jones, the Healy Model, and the Industry Model are able to detect earnings management. However, with respect to the DeAngelo Model, their findings differ from ours. While they conclude that this model is also successful in detecting earnings management, our findings do not support the ability of the DeAngelo Model to detect earnings management.

While our matched-pair design alleviates concerns regarding the role of potential research confounds, it does not eliminate them entirely as the control firms differ from the test firms with respect to certain firm characteristics. In an effort to assess the effect of potential research confounds on our findings, we replicate the logistic regression tests after augmenting the model with explanatory variables capturing auditors' litigation risk (Lys and Watts 1994) as well as extreme earnings performance (Dechow, Sloan, and Sweeney 1995). The results show that only the two cross-sectional models continue to perform well. The Jones Model, the Modified-Jones Model, the Healy Model and the Industry Model are no longer able to distinguish between firms with clean and qualified audit reports. The results also indicate that two of the proxies for litigation risk (book-to-market ratios and financial leverage) as well as the earnings performance variable are important control variables for studying discretionary accruals. 
The primary contribution of this study lies in our finding that the Cross-Sectional Jones Model and the Cross-Sectional Modified Jones Model, not evaluated by prior research, perform better than their time-series counterparts in detecting earnings management. This result is important for future earnings management research particularly because using a cross-sectional model, rather than its time-series counterpart, should result in a larger sample size that is less subject to a survivorship bias. It will also allow examining samples of firms with short history. Another contribution of this study is that our findings from the multiple logistic regressions demonstrate the importance of controlling for research confounds in earnings management studies and identify three important control variables: book-to-market ratios, financial leverage, and earnings performance.

The next section describes the seven competing discretionary-accruals models we evaluate and outlines the theoretical background underlying our investigation. Section 3 reports the sample selection procedure and describes the data. Section 4 outlines the tests and discusses the results, and the final section concludes the study.

\section{Theoretical background}

\subsection{DISCRETIONARY-ACCRUALS MODELS}

The seven competing discretionary-accruals models considered in this study are described below.

\section{The DeAngelo Model}

The DeAngelo (1986) Model uses the last period's total accruals $\left(\mathrm{TA}_{t-1}\right)$ scaled by lagged total assets $\left(\mathrm{A}_{\mathrm{t}-2}\right)$ as the measure of nondiscretionary accruals. Thus, the model for 
nondiscretionary accruals $\left(\mathrm{NDA}_{\mathrm{t}}\right)$ is:

$$
\mathrm{NDA}_{\mathrm{t}}=\mathrm{TA}_{\mathrm{t}-1} / \mathrm{A}_{\mathrm{t}-2}
$$

The discretionary portion of accruals is the difference between total accruals in the event year $t$ scaled by $A_{t-1}$ and $\mathrm{NDA}_{t}$.

\section{The Healy Model}

The Healy (1985) Model uses the mean of total accruals $\left(\mathrm{TA}_{\tau}\right)$ scaled by lagged total assets $\left(\mathrm{A}_{\tau-1}\right)$ from the estimation period as the measure of nondiscretionary accruals. Thus, the model for nondiscretionary accruals in the event year $t\left(\mathrm{NDA}_{\mathrm{t}}\right)$ is:

$$
\mathrm{NDA}_{\mathrm{t}}=1 / \mathrm{n} \Sigma_{\tau}\left(\mathrm{TA}_{\tau} / \mathrm{A}_{\tau-1}\right)
$$

where:

$\mathrm{NDA}_{\mathrm{t}}$ is nondiscretionary accruals in year $t$ scaled by lagged total assets;

$\mathrm{n}$ is the number of years in the estimation period; and

$\tau$ is a year subscript for years $(\mathrm{t}-\mathrm{n}, \mathrm{t}-\mathrm{n}+1, \ldots, \mathrm{t}-1)$ included in the estimation period.

The discretionary portion of accruals is the difference between total accruals in the event year $t$ scaled by $\mathrm{A}_{\mathrm{t}-1}$ and $\mathrm{NDA}_{\mathrm{t}}$. While the DeAngelo Model, in which the estimation period for nondiscretionary accruals is restricted to the previous year's observation, may appear a special case of the Healy (1985) Model, the two models are quite different. While underlying the DeAngelo Model is the assumption that NDA follow a random walk process, the Healy Model assumes that NDA follow a mean reverting process. 


\section{The Jones Model}

Jones (1991) proposes a model that attempts to control for the effects of changes in a firm's economic circumstances on nondiscretionary accruals. The Jones Model for nondiscretionary accruals in the event year is:

$$
\mathrm{NDA}_{t}=\alpha_{1}\left(1 / \mathrm{A}_{\mathrm{t}-1}\right)+\alpha_{2}\left(\Delta \mathrm{REV}_{\mathrm{t}} / \mathrm{A}_{\mathrm{t}-1}\right)+\alpha_{3}\left(\mathrm{PPE}_{\mathrm{t}} / \mathrm{A}_{\mathrm{t}-1}\right)
$$

where:

$\mathrm{NDA}_{\mathrm{t}}$ is nondiscretionary accruals in year $t$ scaled by lagged total assets;

$\Delta \mathrm{REV}_{\mathrm{t}}$ is revenues in year $t$ less revenues in year $t-1$;

$\mathrm{PPE}_{\mathrm{t}}$ is gross property plant and equipment at the end of year $t$;

$\mathrm{A}_{\mathrm{t}-1}$ is total assets at the end of year $t-1$; and

$\alpha_{1}, \alpha_{2}, \alpha_{3}$ are firm-specific parameters.

Estimates of the firm-specific parameters, $\alpha_{1}, \alpha_{2}$, and $\alpha_{3}$, are obtained by using the following model in the estimation period:

$$
\mathrm{TA}_{\mathrm{t}} / \mathrm{A}_{\mathrm{t}-1}=\mathrm{a}_{1}\left(1 / \mathrm{A}_{\mathrm{t}-1}\right)+\mathrm{a}_{2}\left(\Delta \mathrm{REV}_{\mathrm{t}} / \mathrm{A}_{\mathrm{t}-1}\right)+\mathrm{a}_{3}\left(\mathrm{PPE}_{\mathrm{t}} / \mathrm{A}_{\mathrm{t}-1}\right)+\varepsilon_{\mathrm{t}}
$$

where:

$\mathrm{a}_{1}, \mathrm{a}_{2}$, and $\mathrm{a}_{3}$ denote the OLS estimates of $\alpha_{1}, \alpha_{2}$, and $\alpha_{3}$, and $\mathrm{TA}_{\mathrm{t}}$ is total accruals in year $t$. $\varepsilon_{\mathrm{t}}$ is the residual, which represents the firm-specific discretionary portion of total accruals. Other variables are as in equation (3).

\section{The Modified Jones Model}

The Modified Jones Model is designed to eliminate the conjectured tendency of the Jones Model to measure discretionary accruals with error when discretion is exercised over revenue 
recognition. In the modified model, nondiscretionary accruals are estimated during the event year (i.e., the year in which earnings management is hypothesized) as:

$$
\mathrm{NDA}_{\mathrm{t}}=\alpha_{1}\left(1 / \mathrm{A}_{\mathrm{t}-1}\right)+\alpha_{2}\left[\left(\Delta \mathrm{REV}_{\mathrm{t}}-\Delta \mathrm{REC}_{\mathrm{t}}\right) / \mathrm{A}_{\mathrm{t}-1}\right]+\alpha_{3}\left(\mathrm{PPE}_{\mathrm{t}} / \mathrm{A}_{\mathrm{t}-1}\right)
$$

where:

$\Delta \mathrm{REC}_{\mathrm{t}}$ is net receivables in year $t$ less net receivables in year $t-1$, and the other variables are as in equation (3). It is important to note that the estimates of $\alpha_{1}, \alpha_{2}, \alpha_{3}$ are those obtained from the original Jones Model, not from the modified model. The only adjustment relative to the original Jones Model is that the change in revenues is adjusted for the change in receivables in the event year (i.e., in the year earnings management is hypothesized). ${ }^{1}$

\section{The Industry Model}

The Industry Model also relaxes the assumption that nondiscretionary accruals are constant over time. Instead of attempting to model the determinants of nondiscretionary accruals directly, the Industry Model assumes that the variation in the determinants of nondiscretionary accruals are common across firms in the same industry. The Industry Model for nondiscretionary accruals is:

$$
\mathrm{NDA}_{t}=\beta_{1}+\beta_{2} \text { median }_{j}\left(\mathrm{TA}_{\mathrm{t}} / \mathrm{A}_{\mathrm{t}-1}\right)
$$

where:

$\mathrm{NDA}_{t}$ is as in equation (3), and median ${ }_{\mathrm{j}}\left(\mathrm{TA}_{\mathrm{t}} / \mathrm{A}_{\mathrm{t}-1}\right)$ is the median value of total accruals in year $t$ scaled by lagged total assets for all non-sample firms in the same two-digit standard industrial

\footnotetext{
${ }^{1}$ This approach follows from the assumption (underlying all discretionary-accrual models) that during the estimation period, there is no systematic earnings management.
} 
classification (SIC) industry (industry $\mathrm{j}$ ) . The firm-specific parameters $\beta_{1}$ and $\beta_{2}$ are estimated using OLS on the observations in the estimation period.

The Industry Model, the Healy Model, and the Jones Model are estimated over an eightyear period ending just prior to the event year. ${ }^{2}$ For example, discretionary accruals for the first sample year 1980 are computed on the basis of models estimated over the eight-year period, 1972 - 1979, discretionary accruals for the second sample year, 1981, are computed on the basis of models estimated over the period 1973 - 1980, etc. This choice of estimation period, which is comparable to prior research (see, e.g., Dechow, Sloan, and Sweeney 1995, 203), represents a tradeoff. While using long time series of observations improves estimation efficiency, it also leads to a smaller sample size and increases the likelihood of a structural change occurring during the estimation period.

\section{Cross-Sectional Models}

The two cross-sectional models this study is first to examine are the Cross-Sectional Jones Model and the Cross-Sectional Modified Jones Model. These two models are similar to the Jones and Modified Jones models, respectively, except that the parameters of the models are estimated by using cross-sectional, not time-series, data (see, e.g., DeFond and Jiambalvo 1994). Thus, the parameter estimates, $\alpha_{1}, \alpha_{2}$, and $\alpha_{3}$, of equation (3) are industry and year specific rather than firm specific, and are obtained by estimating equation (4) using data from all firms matched on year (i.e., the event year) and two-digit SIC industry groupings.

We note that each type of model relies on a different set of assumptions that are unlikely

\footnotetext{
${ }^{2}$ Note that the Modified Jones Model's parameter estimates are obtained from the Jones Model.
} 
to hold for all firms. The choice between the time-series version and the cross-sectional version of the Jones Model thus represents tradeoffs, and it is an empirical question which choice is preferable. For example, while an assumption underlying the time-series version is that the length of a firm's operating cycle does not change over the estimation period and the event year, underlying the cross-sectional version is an assumption that all firms in the same industry have a similar operating cycle. Indeed, in reality both assumptions are unlikely to hold for all firms. Still, if our sample consists primarily of mature firms, the changes overtime should not be significant. And if our sample firms are not much different from the average firm in their industry, the fact that the cross-sectional version forces the coefficients to be the same for all firms in the industry should not represent a serious problem. Should, however, the discretionary accruals generated by the models reflect primarily these limitations, not the component of earnings manipulated by management, we would not expect to find systematic differences in discretionary accruals between test and control samples appropriately matched, as these limitations should have a similar effect on both samples.

\section{Total Accruals}

The empirical estimation of all seven models involves computing total accruals (TA). Along the lines of prior research (e.g., Healy 1985, and Jones 1991), we use the balance sheet approach to compute TA as follows:

$$
\mathrm{TA}_{\mathrm{t}}=\Delta \mathrm{CA}_{\mathrm{t}}-\Delta \mathrm{Cash}_{\mathrm{t}}-\Delta \mathrm{CL}_{\mathrm{t}}+\Delta \mathrm{DCL}_{\mathrm{t}}-\mathrm{DEP}_{\mathrm{t}}
$$

where:

$\Delta \mathrm{CA}_{\mathrm{t}}$ is the change in current assets in year $t$ (Compustat data \# 4);

$\Delta \operatorname{Cash}_{\mathrm{t}}$ is the change in cash and cash equivalents in year $t$ (Compustat data \# 1); 
$\Delta \mathrm{CL}_{\mathrm{t}}$ is the change in current liabilities in year $t$ (Compustat data \# 5);

$\Delta \mathrm{DCL}_{\mathrm{t}}$ is the change in debt included in current liabilities in year $t$ (Compustat data \# 34); and $\mathrm{DEP}_{\mathrm{t}}$ is depreciation and amortization expense in year $t$ (Compustat data \# 14).

Collins and Hribar (1999) argued that using this balance sheet approach to compute total accruals is inferior in certain circumstances to a cash-flows-statement based approach. Because statement-of-cash-flows data are available only from 1987 and because the time-series models we evaluate require nine years of data, we are unable to measure accruals using the statement of cash flows. Still, we can report that the rank correlation between our measure of total accruals and that based on the statement of cash flows--for a small subset of firms for which cash flows data were available--was 0.96 . This high correlation, which was highly statistically significant, alleviates concerns that the balance sheet approach contaminates our tests.

\subsection{DISCRETIONARY ACCRUALS AND AUDIT QUALIFICATIONS}

The standard agency cost model portrays the role of the auditor as a monitoring mechanism to reduce agency costs (see, e.g., Jensen and Meckling 1976). Agency costs include managers' incentives to manage earnings. Kinney and Martin (1994) reviewed nine studies and concluded that auditing reduces positive bias in pre-audit net earnings and net assets. Hirst (1994) also demonstrated that auditors are sensitive to earnings manipulations through both income-increasing accruals and income-decreasing accruals, and that they are able to detect management incentives to manipulate earnings. Tests involving the association between audit qualifications and stock returns indicate that investors perceive qualified audit reports as informative. Dopuch, Holthausen and Leftwich (1986), Choi and Jeter (1992), and Loudder, Khurana and Sawyers (1992) all reported negative stock price reactions to audit qualifications. 
Our goal is to evaluate the ability of various discretionary-accruals models to detect earnings management by testing the association between a firm's discretionary accruals generated by a model and the firm's likelihood of receiving a qualified audit report. If discretionary accruals produced by a model indicate earnings management, then the higher the discretionary accruals in absolute value, the higher should be the probability for a qualified audit report. Our testing approach follows from the methods of prior earnings management research (see, e.g., Healy 1985, DeAngelo 1986, and Jones 1991), which have relied on discretionary accruals to detect earnings manipulations.

Still, the extent to which auditors are expected to detect earnings management depends on the quality of the audit. DeAngelo (1981) defined audit quality as the joint probability of detecting and reporting material financial statement errors, which will depend in part on the auditor's independence. Higher quality audit firms are expected to hire skilled professionals who can develop more effective tests for detecting earnings management. Moreover, higher quality auditors are less willing to accept questionable accounting practices and more likely to report errors and irregularities.

Big-Six auditors are identified in the literature as higher quality auditors (see, e.g., Palmrose 1988, 63), as they have the technological capability in detecting earnings management, and when detected, there is a higher probability that they will report it. Investors seem to agree with this claim. Teoh and Wong (1993), for example, reported that earnings response coefficients of firms audited by Big-Eight firms are higher than those of firms audited by nonBig-Eight firms, and concluded that the market perceives financial information audited by BigEight firms as more credible. This discussion leads us to perform a supplementary test that examines qualified audit reports produced by Big-Six and non-Big-Six audit firms separately. 


\section{Data}

The sample selection procedure and its effects on the sample size are summarized in Table 1. Initially, 112,384 firm-year observations for the 18-year period, $1980-1997$, are retrieved from the annual Compustat database. Our sample period commences in 1980 because 1972 is the first year for which the annual Compustat data are available for us, and because the estimation of the parameters of the time-series version of the Jones Model requires eight years of data. Next, we delete all firm years with unqualified audit reports, reducing the sample size to 2,333 firm years. We also drop 1,464 firm years with second or more audit qualifications during our sample period, decreasing our sample size to 869 distinct firms. We then eliminate 668 firms due to a lack of sufficient time-series data for estimating the Jones Model or for computing the event year's discretionary accruals for the Modified Jones Model, reducing the sample size to 201 firms. Next, we delete 27 firms with missing control-variable data required for the multiple regression analyses, reducing the sample size to 174 firms. Finally, we delete 8 firms due to unavailability of a matched pair, reducing the final size of the test sample to 166 distinct firms.

Discretionary accruals for the DeAngelo Model and the Healy Model are calculated as the difference between total accruals scaled by lagged total assets in the event year and the average of that variable in the estimation period, which is restricted to one year for the former. We calculate the industry median discretionary accruals for each year, which is required to estimate the Industry Model, based on two-digit SIC groupings. Thus, estimating these three models does not represent additional data requirements.

Each firm year of the test sample is matched with a control firm with an unqualified audit report in the event year. We select the control sample using the following four criteria: (1) fiscal 
year, (2) two-digit SIC code, (3) auditor type (Big Six, non-Big Six), and (4) nearest total assets amount.

Auditor's opinion is the annual Compustat data \# 149, which ranges from 0 to 5 . To be selected as our test sample, a firm has to have a qualified opinion (a value of 2), and to qualify for our control sample, a firm has to have an unqualified opinion (a value of 1 ). ${ }^{3}$ The code description defines a qualified opinion (code 2) as one in which "financial statements reflect the effects of some limitation on the scope of the examination or some unsatisfactory presentation of financial information." An example of an auditor's opinion coded as 2 by Compustat is the 1987 audit report of Boston Edison Co., issued by Coopers \& Lybrand, which states “...the company has incurred significant replacement fuel and power costs.... Such amounts have been billed to customers but are subject to possible refund...."4

Table 2 describes the industry distribution of the qualified audit sample by two-digit SIC codes. Our sample firm years are in 35 different two-digit standard industrial classifications. Thus our sample contains a broad cross-section of firms. While in general there is no evidence of industry clustering within our sample, about 30 percent of the sample firms are in the Electric, Gas, and Sanitary Service industry (SIC 49). In the next section, we thus evaluate the effect of the firms in this industry on our findings.

Table 3 provides descriptive statistics for the qualified-auditor-opinion test sample and the unqualified-auditor-opinion control sample, as well as p-values of non-parametric tests for

\footnotetext{
${ }^{3}$ Codes not included in our sample are: code 0 , unaudited financial statements, code 3 , a going concern qualification, code 4 unqualified opinion with explanatory language, and code 5 adverse opinion. Adverse opinions, code 5, are not included, as they did not exist in our sample period.

${ }^{4}$ Recording revenue when important uncertainties exist is a common misapplication of accounting principles in situations where management attempts to distort the real financial performance of a firm (see, e.g., Schilit 1993, pp. 1-2).
} 
equality between the two samples. From reading across the table, we note two points. First, all variables contain outlying observations, as evidenced by the minimum and maximum before winsorization. This is to be expected when accounting data are pooled over time and across firms. To alleviate this problem, we winsorize all variables so that the minimum and maximum values of each variable lie within three standard deviations from its mean. ${ }^{5}$ Second, there is little difference between the test and control firms with respect to total assets, current assets, and inventory turnover ratio. Thus, our matching procedure is quite successful in creating a control sample that is similar to the test sample with respect to three important firm characteristics. These similarities alleviate concerns that differences between our test and control samples with respect to a firm's stage in its life cycle or the length of its operating cycle confound our tests. Still, the procedure is not fully successful as the test and control samples are different in terms of market capitalization, book-to-market ratios, financial leverage, which may proxy for litigation risk (see Lys and Watts 1994), and earnings performance. In the latter part of the next section, we thus perform multiple regression analyses that evaluate whether these differences confound our tests.

Finally, Table 4 displays a comparison between the parameter estimates generated by the time-series version and those generated by the cross-sectional version of the Jones Model. The results indicate that the standard deviation of all parameter estimates generated by the crosssectional models are substantially lower than their time-series counterparts, the number of outliers is smaller, and the percentage of estimates with the predicted signs is greater. Additionally, the number of observations available for estimating the model is typically much

\footnotetext{
${ }^{5}$ Winsorizing at five standard deviations left the results unchanged.
} 
higher for the cross-sectional version. For example, the median number of observations for the cross-sectional version is 140 and for the time-series version is 8 . Similar findings have also been documented by Subramanyam (1996, Table 1) notwithstanding differences in sample size (166 vs. 21,135 firms years), time period (1980-1997 vs. 1973-1993), and sample selection criteria (carefully selected sample vs. randomly selected sample). The similarity between the results of the two studies alleviates concerns that our non-random sample leads to biased results and thus elevates confidence in the validity of our findings.

\section{Tests and Results}

\subsection{UNIVARIATE TESTS}

We begin our formal assessment of the relative performance of the various discretionaryaccruals models in detecting earnings management by conducting univariate chi-square tests and logistic regression tests that do not consider potential research confounds. For the chi-square tests, we combine the control and test firms into one sample, and assign them to five quintiles on the basis of the absolute value of their discretionary accruals: firms with the smallest (largest) discretionary accruals are assigned to the first (fifth) discretionary-accruals quintile. A discretionary-accruals model that successfully separates earnings into its components, nondiscretionary earnings and discretionary accruals, should generate a relatively high number of unqualified (control) firms assigned to the first quintile and a relatively high number of qualified (test) firms assigned to the fifth quintile. As mentioned above, the intuition of this approach follows from a maintained hypothesis underlying prior earnings management studies (see, e.g., Healy 1985, DeAngelo 1986, and Jones 1991) that high discretionary accruals are inevitably coincident with earnings manipulations. 
Table 5 reports the findings from the chi-square tests. ${ }^{6}$ The results are statistically significant in the predicted direction for the two cross-sectional models, the Healy Model, and the Industry Model, and marginally significant for the Jones Model and the Modified-Jones Model. For example, for the Cross-Sectional Jones Model, the number of unqualified (control) firms declines from 31 in the first (low-discretionary-accruals) quintile to 20 in the fifth (highdiscretionary-accruals) quintile, and the number of qualified (test) firms increases from 35 in the first quintile to 46 in the fifth quintile. A chi-square test indicates that the differences between the test and control samples are statistically significant at a 2.5 percent level. For the DeAngelo Model, however, the numbers of control (test) firms in the lowest-discretionary-accruals quintile, 29 (37), are nearly identical to the numbers of control (test) firms in the highest quintile, 31 (35). A chi-square test indicates that the differences between the two samples are statistically insignificant.

Table 6 reports the results for the logit analyses, regressing the audit opinion (a dummy variable set to zero for an unqualified report and to one for a qualified report) on (the absolute values of) discretionary accruals. Consistent with our chi square tests' results, the results in Table 6 show that all models, except the DeAngelo Model which continues to perform poorly, yield a highly statistically significant parameter estimate in the predicted direction on the discretionary accruals variable.

Overall, two preliminary conclusions emerge from the univariate tests. First, with the exception of the DeAngelo Model, our results from the univariate tests, which do not consider

\footnotetext{
${ }^{6}$ Since all our predictions are directional, all tests are one-tailed.
} 
potential research confounds, provide external validation for the findings in Dechow, Sloan, and Sweeney (1995) regarding the ability of the Jones Model, the Modified-Jones Model, the Healy Model, and the Industry Model to detect earnings management. ${ }^{7}$

Second, the performance of the two cross-sectional models is not inferior to that of their time-series counterparts. This implies that future earnings management research should use the cross-sectional models because the use of time-series data results in a substantially smaller sample size and may even lead to a serious survivorship bias. The Cross-Sectional Jones Model is the best choice as, unlike the modified model, it does not use the change-in-receivablesvariable to compute discretionary accruals in the event year and, thus, is likely to result in a somewhat larger sample.

\section{$\underline{4.2}$ MULTIPLE LOGISTIC REGRESSION TESTS}

Prior research has argued that accruals management studies may be plagued with a correlated-omitted-variables problem that may bias the numbers produced by discretionaryaccruals models. While our matched-pair design alleviates this problem, this design is unsuccessful in totally resolving it, as the match was not perfect. In an effort to further address this problem, we perform a multiple logistic regression test that controls for book-to-market ratios, firm size (market capitalization), financial leverage (long-term debt to-total assets ratio), and extreme earnings performance (the absolute change in income from continuing operations in

\footnotetext{
${ }^{7}$ Our results differ from the Dechow, Sloan, and Sweeney's (1995) results with respect to the DeAngelo Model. They (p. 223) ranked the DeAngelo Model last in terms of its ability to detect earnings management, but concluded that it is able to detect earnings management. Our results also show that the DeAngelo Model exhibited the worst performance, but cast doubts on the ability of this model to detect earnings management.
} 
the event year divided by total assets of previous fiscal year end). ${ }^{8}$ These four control variables are selected because the descriptive statistics, reported in Table 3 above, suggest that our test and control samples differ with respect to these variables. Controlling for the first three variables is important because they may proxy for auditors' litigation risk (see, e.g., Lys and Watts 1994, Shu 1999) and thus have explanatory power for auditors' choice to issue a qualified opinion. Controlling for earnings performance is important because results in Dechow, Sloan, and Sweeney (1995, Table 3) imply that a failure to control for this variable may lead to erroneous inferences.

While many factors may determine the signs of the parameters on these four variables, for the interest of brevity, we attempt to predict the sign of each parameter by considering only the impact of the most important factors. Palepu (1986) argued that a high book-to-market ratio indicates asset under-valuation, which increases the likelihood of acquisition. Lys and Watts (1994) documented a positive association between the likelihood of acquisition and litigation risk. Being concern of litigation risk, auditors will thus be more likely to issue a qualified report the higher the book-to-market ratio is, which implies a positive parameter on the book-to-market ratio in our regressions. The sign of the parameter on the firm-size variable is expected to be positive because prior research (see, e.g., Lys and Watts 1994, and Shu 1999) has documented a positive correlation between firm size and litigation risk. The sign of the parameter on the financial leverage variable is expected to be positive, as higher leverage implies higher bankruptcy risk (see Ohlson 1980) and consequently higher litigation risk. Finally, the estimate

\footnotetext{
${ }^{8}$ The results were unchanged when we scaled the change in earnings in the event year by the absolute value of earnings in year $t-1$ rather than by total assets.
} 
on the extreme earnings performance variable is expected to be positive for two reasons. First, results in Dechow, Sloan and Sweeney (1995, Table 3) imply that discretionary-accruals models produce low (high) discretionary accruals for firm-years with low (high) earnings because they fail to completely extract the non-discretionary accruals of firms experiencing extreme earnings performance. Second, other things being equal, auditors may be more likely to issue qualified reports for firms with extreme earnings, perhaps to mitigate litigation risk.

A problem may arise, however, from adding these explanatory variables to the regressions, as they contain outlying observations (see Table 3 above). As before, we address this problem by winsorizing all explanatory variables at three standard deviations.

Table 7 reports the results of the logistic regressions, regressing the audit opinion (a dummy variable set to zero for an unqualified report and to one for a qualified report) on (the absolute values of) discretionary accruals and the four control variables. There are two points to notice. First, only the Cross-Sectional Jones Model and the Cross-Sectional Modified Jones Model successfully distinguish between firms with qualified audit reports and firms with unqualified reports. For these two models, the parameter estimates on the discretionary accruals variable are positive and highly statistically significant. In contrast, the Jones Model, the Modified-Jones Model, the Industry Model, the DeAngelo Model, and the Healy Model fail to generate significant results. ${ }^{9}$ These results demonstrate the superiority of the cross-sectional models vis-à-vis their time-series counterparts and thus reinforce our conclusion that future accruals management research should use the former rather than the latter. Second, three of the

\footnotetext{
${ }^{9}$ We further assess the sensitivity of our results by adding to the logistic regression a variable capturing past earnings performance. The results, not reported for parsimony, are unchanged.
} 
four control variables, book-to-market ratios, financial leverage, and earnings performance are significant in all models. This finding highlights the importance of controlling for these three variables in accruals management studies. ${ }^{10}$

Recall that about 30 percent of our sample firms are in the Electric, Gas, and Sanitary Service industry (SIC 49). To evaluate whether this subset of firms alone causes our results, we replicate the tests in Table 7 after removing all firms in this industry. The results displayed in Table 8 show that the performance of five of the models evaluated remains unchanged. Specifically, the two cross-sectional models continues to perform well and their time-series counterparts as well as the DeAngelo Model continue to perform poorly. However, the performances of the Industry Model and the Healy Model are improved in that the relation between discretionary accruals and audit qualifications becomes significant for the former and marginally significant for the latter.

\subsection{Big Six Auditors vs. Non-Big Six Auditors}

Finally, we assess specifications that consider differential audit quality between Big Six auditors and non-Big Six auditors. As discussed above, this analysis follows because Big Six auditors are identified in the literature as higher quality auditors (see, e.g., Palmrose 1988, p. 63) due to their technological capability in detecting earnings management, and once detected, a higher probability of reporting it. We thus replicate the logit analysis after adding a dummy variable on the discretionary accruals variable. This dummy variable is set to zero for Big Six

\footnotetext{
${ }^{10}$ The insignificant results for the firm-size variable should be interpreted with caution. This follows because our test and control samples were matched on firm size. Thus, the insignificant results may follow because the sample variation with respect to firm size was insufficient to allow the regression to pick up its effect.
} 
auditors (144 firms) and to one for non-Big Six auditors (22 firms). Thus, if Big Six auditors are of higher quality, the coefficient on the additional variable should be negative. Table 9 reports the results for this sensitivity analysis. The results are consistent with the results for the full sample reported in Table 7. Specifically, the cross-sectional versions of the Jones Model and the Modified Jones Models generate significant estimates on the discretionary-accruals variable, while the other five models continue to perform poorly. The estimates on the additional variable that captures differential audit quality are, as predicted, negative for all models, but statistically insignificant. This statistical insignificance may represent low power due to the small number of firms (22) with a non-Big Six auditor. Overall, these findings reinforce our findings for the full sample.

\section{Conclusion}

Prior evaluations of the ability of alternative discretionary-accruals models to separate earnings to discretionary accruals and nondiscretionary earnings yielded conflicting results. Dechow, Sloan, and Sweeney (1995) concluded that all models appear well specified, generate tests of low power for earnings management, and the Modified Jones Model generates the fewest type II errors. Still, all models reject the null hypothesis of no earnings management at rates exceeding the specified test-levels when applied to samples of firms with extreme financial performance. Guay, Kothari, and Watts (1996) attempted to improve on the methodology for evaluating discretionary-accruals models of this prior research. They first made predictions on the basis of explicit assumptions regarding the relation between stock returns, and discretionary accruals and nondiscretionary earnings, and then investigated whether the alternative accrualbased models produce discretionary accruals and nondiscretionary earnings that conform to their 
predictions. Unlike Dechow, Sloan, and Sweeney (1995), their findings cast doubts on the ability of the models to separate accruals into discretionary and nondiscretionary components. Thus, whether these discretionary-accruals models are able to separate accruals into discretionary and nondiscretionary components and thereby detect earnings management is still an open empirical question.

The primary objective of this study is to evaluate the ability of two cross-sectional models, the Cross-Sectional Jones Model and the Cross-Sectional Modified Jones Model, to detect earnings management vis-à-vis their time-series counterparts. The motivation follows because the two cross-sectional models have not been evaluated by prior research, and because, ex ante, it is unclear which type of model dominates, as each type relies on a different set of assumptions and it is an empirical question which set is more descriptively valid.

The evaluation involves examining the association between discretionary accruals and audit qualifications. An association between large discretionary accruals generated by a model and an audit qualification provides evidence on the ability of the model to detect earnings management.

Results from univariate chi square tests and logit tests that do not fully control for potential research confounds show that all models, except the DeAngelo Model, are successful in discriminating between firms that manage earnings and firms that do not. Once potential research confounds are controlled, however, only the two cross-sectional models are able to consistently detect earnings management.

The contribution of this study is twofold. First, we show that the Cross-Sectional Jones Model and the Cross-Sectional Modified Jones Model, not evaluated by prior research, perform better than their time-series counterparts in detecting earnings management. This result is 
important for future earnings management research particularly because using a cross-sectional model rather than its time-series counterpart should result in a larger sample size that is less subject to a survivorship bias. It will also allow examining samples of firms with short history. Second, we demonstrate that correlated omitted variables represent a serious problem for accrual management studies, and identify three such variables (i.e., book-to-market ratios, financial leverage, and earnings performance). 


\section{References}

CHANEY, P. K., D. C. JETER, AND C. M. LEWIS. 1995. "The Use of Accruals in Earnings Management; A Permanent Earnings Hypothesis." Working paper, Vanderbilt University.

CHOI, S. K., AND D.C. JETER. 1992. "The Effect of Qualified Audit Opinion on Earnings Response Coefficients." Journal of Accounting and Economics 14, 229-247.

COLLINS, D. W., AND P. Hribar. 1999. "Errors in Estimating Accruals: Implications for Empirical Research.” Working Paper, University of Iowa.

DEANGELO, L. 1981. "Auditor Size and Auditor Quality." Journal of Accounting and Economics 1, 113-127.

. 1986. "Accounting Numbers as Market Valuation Substitutes: A Study of Management Buyouts of Public Shareholders." The Accounting Review 61, 400-420.

DECHOW, P.M., R.G. SLOAN, AND A.P. SWEENEY. 1995. "Detecting Earnings Management." The Accounting Review 70, 193-225.

DEFOND, M. L., AND J. JIAMBALVO. 1994. "Debt Covenant Violation and Manipulation of Accruals." Journal of Accounting and Economics 17, 145-176.

DOPUCH, N., R. HOLTHAUSEN, AND R. LEFTWICH. 1986. “Abnormal Stock Returns Associated with Media Disclosures of 'Subject to' Qualified Audit Opinions.” Journal of Accounting and Economics 8, 93-118.

GUAY, W. R., S. P. KOTHARI, AND R. L. WATTS. 1996. “A Market-Based Evaluation of Discretionary Accrual Models." Journal of Accounting Research 34 (Supplement), 83105.

HANSEN, G. A. 1996. "Do Discretionary Accrual Proxies Measure Earnings Management?" Working paper, University of Rochester.

HEALY, P. M. 1985. "The Effect of Bonus Schemes on Accounting Decisions." Journal of Accounting and Economics 7, 85-107.

. 1996. "Discussion of A Market-Based Evaluation of Discretionary Accrual Models." Journal of Accounting Research 34, 107-114.

HIRST, D. E. 1994. “Auditor Sensitivity to Earnings Management.” Contemporary Accounting Research 11, 405-422. 
JENSEN, M., AND W. MECKLING. 1976. "Theory of the Firm: Managerial Behaviour, Agency Costs and Ownership Structure." Journal of Financial Economics 3, 305-360.

JONES, J. 1991. "Earnings Management During Import Relief Investigations." Journal of Accounting Research 29, 193-228.

KINNEY, W., AND R. MARTIN. 1994. "Does Auditing Reduce Bias in Financial Reporting? A Review of Audit-Related Adjustment Studies." Auditing: A Journal of Practice and Theory 13, 149-156.

LOUDDER, M. L., I. K. KHURANA, R. B. SAWYERS, C. CORDERY, C. JOHNSON, J. LOWE, AND R. WUNDERLE. 1992. "The Information Content of Audit Qualifications." Auditing: A Journal of Practice \& Theory 11, 69-82.

LYS, T., AND R. L. WATTS. 1994. "Lawsuits Against Auditors." Journal of Accounting Research 32 Supplement, 65-93.

OHLSON, J. A. 1980. "Financial Ratios and the Probabilistic Prediction of Bankruptcy." Journal of Accounting Research 18, 109-131.

SCHILIT, H. M. "Financial Shenanigans: How to Detect Accounting Gimmicks \& Fraud in Financial Reports." New York: McGraw-Hill, Inc.

SHU, S. 1999. "Auditors Resignations: Clientele Effects and Legal Liability.” Working paper, Boston College.

TEOH, S.H., AND T.J. WONG. 1993. "Perceived Auditor Quality and the Earnings Response Coefficient." The Accounting Review 68, 346-367.

PALEPU, K. G. 1986. "Predicting Takeover Targets: A Methodological and Empirical Analysis." Journal of Accounting and Economics 8, 3-35.

PALMROSE, Z. 1988. "An analysis of Auditor Litigation and Audit Service Quality." The Accounting Review 63, 55-73.

SUBRAMANYAM, K. R. 1996. "The Pricing of Discretionary Accruals." Journal of Accounting and Economics 22, 249-282. 
Table 1

Summary of the Sample Selection Criteria

Completed firm years 80-97

112,384

Less firm years with unqualified or unavailable audit reports

$\underline{110,051}$

Firm years with qualified audit reports

Less firm years with second or more qualifications during our sample period

Distinct firms with an audit qualification

Less firms with insufficient data for discretionary-accruals calculation

Firms with an audit qualification and data for discretionary-accruals calculation

Less firms with missing control variable data ${ }^{1}$

Firms with an audit qualification and complete data

Less firms not meeting requirements for matched pair $^{2}$

Big Six auditor

non-Big Six auditor

${ }^{1}$ Firms with a missing or negative book value, missing market value, debt-to-total assets ratio, or earnings are deleted.

${ }^{2}$ An unqualified matched pair control sample was selected based on year, industry, auditor type, and total assets. 
Table 2

Industry Distribution of Qualified Firm Years by Two-Digit Standard Industrial Classification Codes

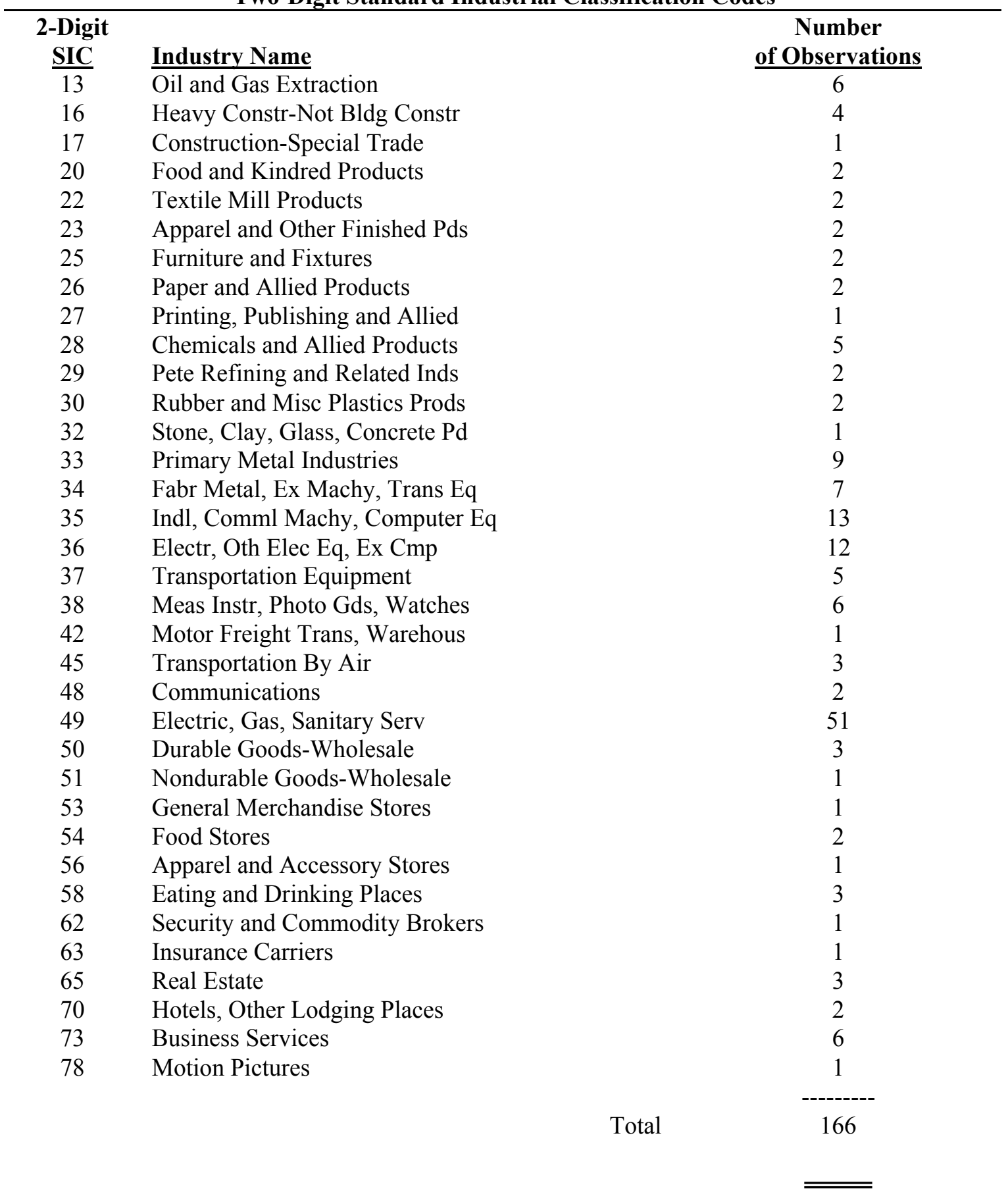


Table 3

Descriptive Statistics

\begin{tabular}{|c|c|c|c|c|c|c|c|c|c|c|c|c|c|}
\hline & \multicolumn{6}{|c|}{ Qualified (Test) Sample } & \multicolumn{6}{|c|}{ Unqualified (Control) Sample } & \multirow{2}{*}{$\begin{array}{c}\text { Prob } \\
\left(\text { Median }_{\text {control }} \text { : }\right. \\
\left.\text { Median }_{\text {test }}\right)^{*}\end{array}$} \\
\hline & $\mathrm{N}$ & Mean & Std D & Median & Min & Max & $\mathrm{N}$ & Mean & Std D & Median & Min & Max & \\
\hline $\begin{array}{l}\text { Total Assets } \\
\text { (millions) }\end{array}$ & $\begin{array}{r}166 \\
(8)\end{array}$ & 1443.097 & 2337.123 & 238.048 & $\begin{array}{r}0.449 \\
(0.449)\end{array}$ & $\begin{array}{r}8454.466 \\
(37703.00)\end{array}$ & $\begin{array}{l}166 \\
(7)\end{array}$ & 1415.332 & 2332.370 & 217.728 & $\begin{array}{r}1.973 \\
(1.973)\end{array}$ & $\begin{array}{l}8412.442 \\
(38899.01)\end{array}$ & 0.947 \\
\hline $\begin{array}{l}\text { Current Assets } \\
\text { (millions) }\end{array}$ & $\begin{array}{r}166 \\
(8)\end{array}$ & 220.923 & 308.274 & 78.194 & $\begin{array}{r}0.114 \\
(0.114)\end{array}$ & $\begin{array}{r}1145.744 \\
(10934.00)\end{array}$ & $\begin{array}{l}166 \\
(6)\end{array}$ & 234.233 & 314.282 & 87.221 & $\begin{array}{c}1.251 \\
(1.251)\end{array}$ & $\begin{array}{r}1177.080 \\
(11678.00)\end{array}$ & 0.545 \\
\hline $\begin{array}{l}\text { Market Value of } \\
\text { Equity (millions) }\end{array}$ & $\begin{array}{r}166 \\
(0)\end{array}$ & 508.896 & 1373.875 & 68.156 & $\begin{array}{r}0.396 \\
(0.396)\end{array}$ & $\begin{array}{l}13911.75 \\
(13911.75)\end{array}$ & $\begin{array}{l}166 \\
(0)\end{array}$ & 670.391 & 1416.795 & 143.341 & $\begin{array}{c}1.686 \\
(1.686)\end{array}$ & $\begin{array}{l}13042.91 \\
(13042.91)\end{array}$ & 0.011 \\
\hline $\begin{array}{l}\text { Book-to-Market } \\
\text { Ratio }\end{array}$ & $\begin{array}{r}166 \\
(4)\end{array}$ & 1.163 & 0.812 & 1.018 & $\begin{array}{r}0.003 \\
(0.003)\end{array}$ & $\begin{array}{l}3.601 \\
(8.740)\end{array}$ & $\begin{array}{l}166 \\
(1)\end{array}$ & 0.888 & 0.404 & 0.870 & $\begin{array}{c}0.018 \\
(0.018)\end{array}$ & $\begin{array}{c}2.099 \\
(2.501)\end{array}$ & 0.004 \\
\hline $\begin{array}{l}\text { Long-term Debt / } \\
\text { Total Assets }\end{array}$ & $\begin{array}{r}166 \\
(0)\end{array}$ & 0.269 & 0.184 & 0.289 & $\begin{array}{r}0 \\
(0)\end{array}$ & $\begin{array}{l}0.747 \\
(0.747)\end{array}$ & $\begin{array}{l}166 \\
(1)\end{array}$ & 0.224 & 0.143 & 0.212 & $\begin{array}{l}0 \\
(0)\end{array}$ & $\begin{array}{c}0.653 \\
(0.705)\end{array}$ & 0.009 \\
\hline PERFORM & $\begin{array}{r}166 \\
(7)\end{array}$ & 0.064 & 0.078 & 0.031 & $\begin{array}{r}0 \\
(0)\end{array}$ & $\begin{array}{l}0.299 \\
(0.466)\end{array}$ & $\begin{array}{l}166 \\
(8)\end{array}$ & 0.029 & 0.034 & 0.015 & $\begin{array}{l}0 \\
(0)\end{array}$ & $\begin{array}{c}0.130 \\
(0.382)\end{array}$ & 0.000 \\
\hline $\begin{array}{l}\text { Inventory } \\
\text { Turnover Ratio t-1 }\end{array}$ & $\begin{array}{l}98 \\
(5)\end{array}$ & 8.020 & 7.362 & 5.049 & $\begin{array}{r}0.847 \\
(0.847)\end{array}$ & $\begin{array}{c}30.107 \\
(52.279)\end{array}$ & $\begin{array}{l}98 \\
(6)\end{array}$ & 7.527 & 6.520 & 5.362 & $\begin{array}{l}0.600 \\
(0.600)\end{array}$ & $\begin{array}{r}27.087 \\
(73.140)\end{array}$ & 0.905 \\
\hline
\end{tabular}


Table 3 (cont'd)

Descriptive Statistics

*Wilcoxon test (two-tailed). Numbers in parenthesis represent the number of firm-years winsorized and the minimum and maximum before winsorization.

All figures are as of fiscal year end of the event year unless otherwise stated.

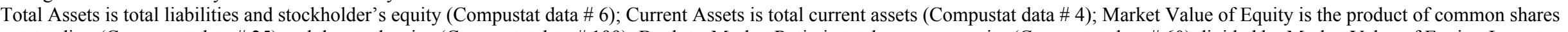

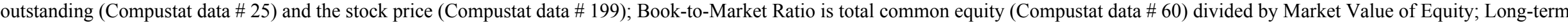

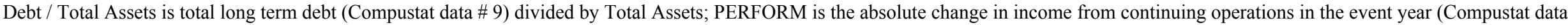

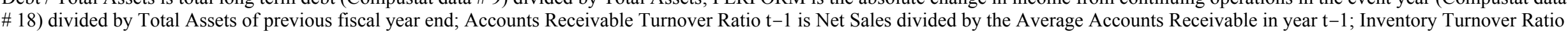
$\mathrm{t}-1$ is Cost of Goods Sold divided by the Average Inventory in year $\mathrm{t}-1$. 
Table 4

Comparison of Alternative Expectation Models for Accruals

Model TA $\mathbf{A}_{\mathbf{t}} / \mathbf{A}_{\mathbf{t}-1}=\alpha_{1}\left(1 / \mathbf{A}_{\mathrm{t}-1}\right)+\alpha_{2}\left(\Delta \mathbf{R E V} / \mathbf{A}_{\mathrm{t}-1}\right)+\alpha_{3}\left(\mathbf{P P E}_{\mathbf{t}} / \mathbf{A}_{\mathrm{t}-1}\right)+\varepsilon_{\mathbf{t}}$

$(\mathrm{N}=166)$

\begin{tabular}{|c|c|c|c|c|c|c|c|}
\hline Model & $\begin{array}{l}\text { Predicted } \\
\text { Sign }\end{array}$ & Mean & Std Dev & Median & Minimum & Maximum & $\%$ positive \\
\hline \multicolumn{8}{|c|}{$\begin{array}{l}\text { Number of observations } \\
\text { per regression }\end{array}$} \\
\hline TS - Jones & & 8 & 0 & 8 & 8 & 8 & --- \\
\hline CS - Jones & & 109.37 & 67.80 & 140 & 7 & 232 & --- \\
\hline \multicolumn{8}{|c|}{ Estimate of $\alpha_{1}$} \\
\hline TS - Jones & & $\begin{array}{l}14.52 \\
(0.02)\end{array}$ & 102.07 & $\begin{array}{c}0.34 \\
(0.16)\end{array}$ & -439.95 & 926.81 & 55.4 \\
\hline CS - Jones & & $\begin{array}{c}0.02 \\
(0.96)\end{array}$ & 0.65 & $\begin{array}{l}0 \\
(0.04)\end{array}$ & -3.05 & 4.52 & 53.6 \\
\hline \multicolumn{8}{|c|}{ Estimate of $\alpha_{2}$} \\
\hline TS - Jones & + & $\begin{array}{c}0.10 \\
(0.69)\end{array}$ & 0.31 & $\begin{array}{c}0.07 \\
(0.71)\end{array}$ & -1.38 & 1.42 & 69.9 \\
\hline CS - Jones & + & $\begin{array}{c}0.11 \\
(3.87)\end{array}$ & 0.11 & $\begin{array}{c}0.09 \\
(2.98)\end{array}$ & -0.17 & 0.44 & 84.9 \\
\hline \multicolumn{8}{|c|}{ Estimate of $\alpha_{3}$} \\
\hline TS - Jones & - & $\begin{array}{l}-0.01 \\
(-0.76)\end{array}$ & 0.33 & $\begin{array}{c}-0.04 \\
(-0.72)\end{array}$ & -1.87 & 1.61 & 29.5 \\
\hline CS - Jones & - & $\begin{array}{l}-0.05 \\
(-4.86)\end{array}$ & 0.06 & $\begin{array}{c}-0.04 \\
(-3.75)\end{array}$ & -0.27 & 0.21 & 7.2 \\
\hline
\end{tabular}

The sample consists of our distinct qualified opinion firms. TS denotes the time-series Jones model originally proposed by Jones (1991). The time series model is estimated from the past time-series for each firm. CS denotes the cross-sectional Jones model as proposed by DeFond and Jiambalvo (1994). The cross-sectional Jones model is similar in form to the time-series Jones model, except it is estimated separately for each combination of calendar year and 2-digit SIC code. Figures in parentheses denote means/medians of individual regression t-statistics.

$\mathrm{TA}_{\mathrm{t}}$ is total accruals in year $t$ (the event year).

$\Delta \mathrm{REV}_{\mathrm{t}}$ is revenues in year $t$ less revenues in year $t-1$

$\mathrm{PPE}_{\mathrm{t}}$ is gross property, plant and equipment at the end of year $t$

$\mathrm{A}_{\mathrm{t}-1}$ is total assets at the end of year $t-1$

$\varepsilon_{\mathrm{t}}$ is the residual 
Table 5

\section{Association Between Absolute Value of Discretionary Accruals and Audit Qualifications: Chi-square Test (Qualified $=166$, Unqualified $=166$ )}

\begin{tabular}{|c|c|c|c|c|c|c|c|c|c|c|}
\hline \multirow[b]{2}{*}{ Qualified } & \multicolumn{2}{|c|}{$\begin{array}{l}\text { Modified-Jones } \\
X^{2}=7.700 \\
p=0.052\end{array}$} & \multicolumn{2}{|c|}{$\begin{array}{l}\text { Cross-sectional Jones } \\
X^{2}=17.747 \\
p=0.001\end{array}$} & \multicolumn{2}{|c|}{$\begin{array}{l}\text { Cross-sectional } \\
\text { Modified-Jones } \\
X^{2}=15.557 \\
\mathrm{p}=0.002\end{array}$} & \multicolumn{2}{|l|}{$\begin{array}{l}\text { Industry } \\
\mathrm{X}^{2}=9.953 \\
\mathrm{p}=0.021\end{array}$} & \multicolumn{2}{|l|}{$\begin{array}{l}\text { DeAngelo } \\
\mathrm{X}^{2}=2.146 \\
\mathrm{p}=0.355\end{array}$} \\
\hline & Unqualified & Qualified & Unqualified & Qualified & Unqualified & Qualified & Unqualified & Qualified & Unqualified & Qualified \\
\hline 34 & 33 & 33 & 31 & 35 & 32 & 34 & 29 & 37 & 29 & 37 \\
\hline 33 & 33 & 34 & 35 & 32 & 30 & 37 & 36 & 31 & 34 & 33 \\
\hline 28 & 37 & 29 & 36 & 30 & 42 & 24 & 40 & 26 & 36 & 30 \\
\hline 29 & 39 & 28 & 44 & 23 & 40 & 27 & 37 & 30 & 36 & 31 \\
\hline 42 & 24 & 42 & 20 & 46 & 22 & 44 & 24 & 42 & 31 & 35 \\
\hline 166 & 166 & 166 & 166 & 166 & 166 & 166 & 166 & 166 & 166 & 166 \\
\hline
\end{tabular}

Note: All p-values are one-tailed. 
Table 6

Association Between Absolute Value of Discretionary Accruals and Audit Qualification

Audit Opinion $=b_{0}+b_{1}(\operatorname{abs}(\mathrm{DA}))+e$

$($ Qualified $=166$, Unqualified $=166)$

\begin{tabular}{|c|c|c|c|c|c|c|}
\hline & & $\begin{array}{l}\text { Expected } \\
\text { Sign }\end{array}$ & Coeff. & $\begin{array}{l}\text { Chi- } \\
\text { square }\end{array}$ & Prob. & $\begin{array}{l}\text { Odds } \\
\text { Ratio }\end{array}$ \\
\hline $\begin{array}{l}\text { Jones Model } \\
\left.\text { (Model Chi-square }=4.779, \mathrm{p}=0.0288^{* *}\right)\end{array}$ & $\begin{array}{l}b_{o} \\
b_{1}\end{array}$ & $\begin{array}{l}? \\
+\end{array}$ & $\begin{array}{r}-0.2125 \\
3.1506\end{array}$ & $\begin{array}{l}2.0929 \\
4.6578\end{array}$ & $\begin{array}{l}0.148 \\
0.015^{* *}\end{array}$ & 23.349 \\
\hline $\begin{array}{l}\text { Modified-Jones Model } \\
\left(\text { Model Chi-square }=4.364, \mathrm{p}=0.0367^{* *}\right)\end{array}$ & $\begin{array}{l}\mathrm{b}_{\mathrm{o}} \\
\mathrm{b}_{1}\end{array}$ & $\begin{array}{l}? \\
+\end{array}$ & $\begin{array}{r}-0.2035 \\
2.9510\end{array}$ & $\begin{array}{l}1.9171 \\
4.2630\end{array}$ & $\begin{array}{l}0.166 \\
0.020^{* *}\end{array}$ & 19.124 \\
\hline $\begin{array}{l}\text { Cross-sectional Jones Model } \\
\left(\text { Model Chi-square }=9.862, p=0.0017^{*}\right)\end{array}$ & $\begin{array}{l}b_{o} \\
b_{1}\end{array}$ & $\begin{array}{l}? \\
+\end{array}$ & $\begin{array}{r}-0.3011 \\
4.9327\end{array}$ & $\begin{array}{l}4.2365 \\
9.2865\end{array}$ & $\begin{array}{l}0.040^{* *} \\
0.001^{*}\end{array}$ & 138.752 \\
\hline $\begin{array}{l}\text { Cross-sectional Modified-Jones Model } \\
\text { (Model Chi-square }=7.703, p=0.0055^{*} \text { ) }\end{array}$ & $\begin{array}{l}b_{o} \\
b_{1}\end{array}$ & $\begin{array}{l}? \\
+\end{array}$ & $\begin{array}{r}-0.2621 \\
4.1626\end{array}$ & $\begin{array}{l}3.2576 \\
7.3559\end{array}$ & $\begin{array}{l}0.071 \\
0.003 *\end{array}$ & 64.238 \\
\hline $\begin{array}{l}\text { Industry Model } \\
\text { (Model Chi-square }=6.624, \mathrm{p}=0.0101 * * \text { ) }\end{array}$ & $\begin{array}{l}b_{o} \\
b_{1}\end{array}$ & $\begin{array}{l}? \\
+\end{array}$ & $\begin{array}{r}-0.2528 \\
3.4286\end{array}$ & $\begin{array}{l}2.9311 \\
6.3815\end{array}$ & $\begin{array}{l}0.087 \\
0.006^{*}\end{array}$ & 30.834 \\
\hline $\begin{array}{l}\text { DeAngelo Model } \\
\text { (Model Chi-square }=1.685, \mathrm{p}=0.1943 \text { ) }\end{array}$ & $\begin{array}{l}b_{o} \\
b_{1}\end{array}$ & $\begin{array}{l}? \\
+\end{array}$ & $\begin{array}{r}-0.1211 \\
1.5781\end{array}$ & $\begin{array}{l}0.7057 \\
1.6696\end{array}$ & $\begin{array}{l}0.401 \\
0.098\end{array}$ & 4.846 \\
\hline $\begin{array}{l}\text { Healy Model } \\
\text { (Model Chi-square }=4.918, p=0.0266^{* *} \text { ) }\end{array}$ & $\begin{array}{l}b_{o} \\
b_{1}\end{array}$ & $\begin{array}{l}? \\
+\end{array}$ & $\begin{array}{r}-0.2155 \\
3.3573\end{array}$ & $\begin{array}{l}2.1528 \\
4.7908\end{array}$ & $\begin{array}{l}0.142 \\
0.014 * *\end{array}$ & 28.710 \\
\hline
\end{tabular}

* $\mathrm{p} \leq 0.01$ (one-tailed tests for the slopes, two-tailed tests for the intercepts and the models).

$* * \mathrm{p} \leq 0.05$ (one-tailed tests for the slopes, two-tailed tests for the intercepts and the models).

The chi-square probabilities are for one-tailed tests for the slopes and two-tailed tests for the intercepts.

Audit Opinion is a dummy variable set to 0 for unqualified audit report and to 1 for qualified report.

DA is discretionary accruals. 
Table 7

Association Between Absolute Value of Discretionary Accruals

and Audit Qualification with Controls

$($ Qualified $=166$, Unqualified $=166)$

Model: Audit Opinion $=b_{0}+b_{1}$ BP $+b_{2}$ MKTCAP $+b_{3}$ DE $+b_{4}$ PERFORM +

$\mathbf{b}_{5}(\operatorname{abs}(\mathbf{D A}))+\mathbf{e}$

Jones Model

(Model Chi-square $=66.692, \mathrm{p}=0.0001^{*}$ )

Modified-Jones Model

$\left(\right.$ Model Chi-square $\left.=66.693, \mathrm{p}=0.0001^{*}\right)$

Cross-sectional Jones Model

(Model Chi-square $=70.125, \mathrm{p}=0.0001^{*}$ )

Cross-sectional Modified-Jones Model

$\left(\right.$ Model Chi-square $=68.935, \mathrm{p}=0.0001^{*}$ )

Industry Model

(Model Chi-square $=67.801, \mathrm{p}=0.0001^{*}$ )

DeAngelo Model

$\left(\right.$ Model Chi-square $\left.=66.125, \mathrm{p}=0.0001^{*}\right)$

\begin{tabular}{|c|c|c|c|c|}
\hline $\begin{array}{l}\text { Expected } \\
\text { Sign }\end{array}$ & Coeff. & $\begin{array}{l}\text { Chi- } \\
\text { square }\end{array}$ & Prob. & $\begin{array}{l}\text { Odds } \\
\text { Ratio }\end{array}$ \\
\hline$?$ & -2.6179 & 21.9205 & $0.000 *$ & \\
\hline+ & 1.0957 & 22.2425 & $0.000 *$ & 2.991 \\
\hline+ & -0.1001 & 0.4248 & 0.257 & 0.905 \\
\hline+ & 3.8086 & 19.2100 & $0.000 *$ & 45.087 \\
\hline+ & 15.1437 & 24.9181 & $0.000 *$ & 999.000 \\
\hline+ & 1.7311 & 0.8429 & 0.179 & 5.647 \\
\hline$?$ & -2.6231 & 22.0092 & $0.000 *$ & \\
\hline+ & 1.0960 & 22.2168 & $0.000 *$ & 2.992 \\
\hline+ & -0.0998 & 0.4236 & 0.258 & 0.905 \\
\hline+ & 3.8110 & 19.2196 & $0.000 *$ & 45.194 \\
\hline+ & 15.2053 & 25.2553 & $0.000 *$ & 999.000 \\
\hline+ & 1.7163 & 0.8818 & 0.174 & 5.564 \\
\hline$?$ & -2.9669 & 26.8481 & $0.000 *$ & \\
\hline+ & 1.1309 & 22.9547 & $0.000 *$ & 3.098 \\
\hline+ & -0.0472 & 0.0941 & 0.380 & 0.954 \\
\hline+ & 4.0571 & 21.0606 & $0.000 *$ & 57.805 \\
\hline+ & 14.5769 & 23.1894 & $0.000 *$ & 999.000 \\
\hline+ & 4.7469 & 5.3450 & $0.010^{*}$ & 115.230 \\
\hline$?$ & -2.8727 & 25.5164 & $0.000 *$ & \\
\hline+ & 1.1258 & 22.8229 & $0.000 *$ & 3.083 \\
\hline+ & -0.0634 & 0.1708 & 0.340 & 0.939 \\
\hline+ & 3.9933 & 20.5708 & $0.000 *$ & 54.232 \\
\hline+ & 14.7413 & 23.7102 & $0.000 *$ & 999.000 \\
\hline+ & 3.8348 & 3.8210 & $0.025 * *$ & 46.285 \\
\hline$?$ & -2.7948 & 23.9818 & $0.000 *$ & \\
\hline+ & 1.1159 & 22.8025 & $0.000 *$ & 3.052 \\
\hline+ & -0.0772 & 0.2517 & 0.308 & 0.926 \\
\hline+ & 3.9710 & 20.2829 & $0.000 *$ & 53.035 \\
\hline+ & 14.7885 & 23.7637 & $0.000 *$ & 999.000 \\
\hline+ & 2.7961 & 2.5227 & 0.056 & 16.380 \\
\hline$?$ & -2.4789 & 18.5814 & $0.000 *$ & \\
\hline+ & 1.0830 & 21.6083 & $0.000 *$ & 2.954 \\
\hline+ & -0.1246 & 0.6399 & 0.212 & 0.883 \\
\hline+ & 3.7663 & 18.2131 & $0.000 *$ & 43.219 \\
\hline+ & 15.4954 & 25.9926 & $0.000 *$ & 999.000 \\
\hline+ & 0.4264 & 0.0594 & 0.404 & 1.532 \\
\hline
\end{tabular}


Table 7 (cont'd)

Association Between Absolute Value of Discretionary Accruals

and Audit Qualification with Controls

$($ Qualified $=166$, Unqualified $=166)$

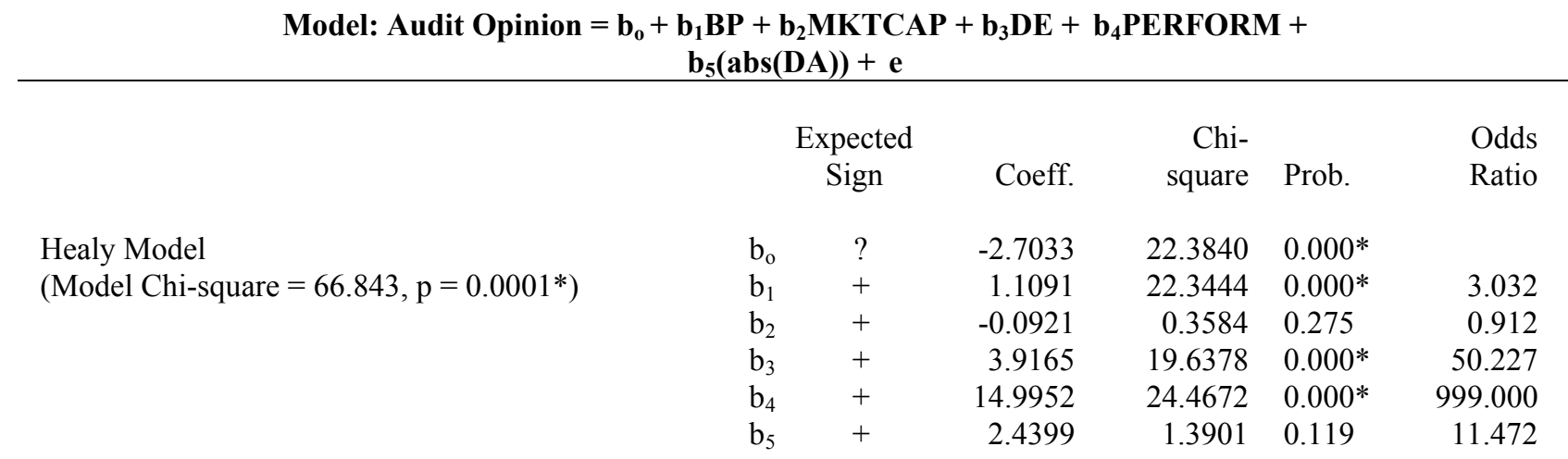

* $\mathrm{p} \leq 0.01$ (one-tailed tests for the slopes, two-tailed tests for the intercepts and the models).

$* * \mathrm{p} \leq 0.05$ (one-tailed tests for the slopes, two-tailed tests for the intercepts and the models).

The chi-square probabilities are for one-tailed tests for the slopes and two-tailed tests for the intercepts and the models.

Audit Opinion is a dummy variable set to 0 for unqualified audit report and to 1 for qualified report.

DA is discretionary accruals as of fiscal year end of the event year.

BP is book-to-market ratio as of fiscal year end of the event year.

MKTCAP is log base 10 of market capitalization as of fiscal year end of the event year.

$\mathrm{DE}$ is long-term debt-to-total asset ratio.

PERFORM is the absolute change in income from continuing operations in the event year divided by the total assets of the previous fiscal year end. 
Table 8

Association Between Absolute Value of Discretionary Accruals and Audit Qualification with Controls Excluding 2-digit SIC Code 49 $($ Qualified $=115$, Unqualified $=115)$

Model: Audit Opinion $=b_{0}+b_{1}$ BP $+b_{2}$ MKTCAP $+b_{3}$ DE $+b_{4}$ PERFORM + $\mathbf{b}_{5}(\operatorname{abs}(\mathbf{D A}))+\mathbf{e}$

\begin{tabular}{|c|c|c|c|c|c|c|}
\hline & & $\begin{array}{l}\text { Expected } \\
\text { Sign }\end{array}$ & Coeff. & $\begin{array}{l}\text { Chi- } \\
\text { square }\end{array}$ & Prob. & $\begin{array}{l}\text { Odds } \\
\text { Ratio }\end{array}$ \\
\hline Jones Model & $\mathrm{b}_{\mathrm{o}}$ & ? & -2.3814 & 15.2043 & $0.000 *$ & \\
\hline \multirow[t]{5}{*}{$\left(\right.$ Model Chi-square $\left.=56.597, \mathrm{p}=0.0001^{*}\right)$} & $\mathrm{b}_{1}$ & + & 0.9214 & 14.8617 & $0.000 *$ & 2.513 \\
\hline & $\mathrm{b}_{2}$ & + & -0.1518 & 0.6482 & 0.210 & 0.859 \\
\hline & $\mathrm{b}_{3}$ & + & 2.9525 & 10.2350 & $0.001 *$ & 19.153 \\
\hline & $\mathrm{b}_{4}$ & + & 15.6719 & 23.6064 & $0.000 *$ & 999.000 \\
\hline & $\mathrm{b}_{5}$ & + & 2.4673 & 1.5818 & 0.104 & 11.791 \\
\hline Modified-Jones Model & $\mathrm{b}_{\mathrm{o}}$ & $?$ & -2.3843 & 15.2748 & $0.000 *$ & \\
\hline \multirow[t]{5}{*}{$\left(\right.$ Model Chi-square $\left.=56.581, \mathrm{p}=0.0001^{*}\right)$} & $\mathrm{b}_{1}$ & + & 0.9211 & 14.8290 & $0.000 *$ & 2.512 \\
\hline & $\mathrm{b}_{2}$ & + & -0.1536 & 0.6677 & 0.207 & 0.858 \\
\hline & $\mathrm{b}_{3}$ & + & 2.9503 & 10.2203 & $0.001 *$ & 19.111 \\
\hline & $\mathrm{b}_{4}$ & + & 15.7770 & 23.9501 & $0.000 *$ & 999.000 \\
\hline & $b_{5}$ & + & 2.4171 & 1.6118 & 0.102 & 11.213 \\
\hline Cross-sectional Jones Model & $\mathrm{b}_{\mathrm{o}}$ & $?$ & -2.7309 & 18.5219 & $0.000 *$ & \\
\hline \multirow[t]{5}{*}{$\left(\right.$ Model Chi-square $\left.=59.440, \mathrm{p}=0.0001^{*}\right)$} & $\mathrm{b}_{1}$ & + & 0.9495 & 15.4152 & $0.000 *$ & 2.584 \\
\hline & $\mathrm{b}_{2}$ & + & -0.0887 & 0.2139 & 0.322 & 0.915 \\
\hline & $\mathrm{b}_{3}$ & + & 3.2488 & 11.8724 & $0.000 *$ & 25.759 \\
\hline & $\mathrm{b}_{4}$ & + & 15.2063 & 22.2874 & $0.000 *$ & 999.000 \\
\hline & $\mathrm{b}_{5}$ & + & 5.2212 & 5.4255 & $0.010 *$ & 185.148 \\
\hline \multirow{6}{*}{$\begin{array}{l}\text { Cross-sectional Modified-Jones Model } \\
\left(\text { Model Chi-square }=58.144, \mathrm{p}=0.0001^{*}\right)\end{array}$} & $\mathrm{b}_{\mathrm{o}}$ & ? & -2.6049 & 17.2144 & $0.000^{*}$ & \\
\hline & $\mathrm{b}_{1}$ & + & 0.9418 & 15.2373 & $0.000 *$ & 2.565 \\
\hline & $\mathrm{b}_{2}$ & + & -0.1116 & 0.3423 & 0.279 & 0.894 \\
\hline & $\mathrm{b}_{3}$ & + & 3.1631 & 11.3825 & $0.000 *$ & 23.645 \\
\hline & $\mathrm{b}_{4}$ & + & 15.3799 & 22.8969 & $0.000 *$ & 999.000 \\
\hline & $b_{5}$ & + & 4.1081 & 3.7322 & $0.027 * *$ & 60.833 \\
\hline \multirow{6}{*}{$\begin{array}{l}\text { Industry Model } \\
\left(\text { Model Chi-square }=57.657, \mathrm{p}=0.0001^{*}\right)\end{array}$} & $b_{o}$ & $?$ & -2.5429 & 16.5718 & $0.000 *$ & \\
\hline & $b_{1}$ & + & 0.9416 & 15.2978 & $0.000 *$ & 2.564 \\
\hline & $\mathrm{b}_{2}$ & + & -0.1336 & 0.4905 & 0.242 & 0.875 \\
\hline & $\mathrm{b}_{3}$ & + & 3.1116 & 11.1058 & $0.000 *$ & 22.458 \\
\hline & $\mathrm{b}_{4}$ & + & 15.5080 & 22.8407 & $0.000 *$ & 999.000 \\
\hline & $\mathrm{b}_{5}$ & + & 3.2409 & 3.2371 & $0.036^{* *}$ & 25.557 \\
\hline \multirow{6}{*}{$\begin{array}{l}\text { DeAngelo Model } \\
\left(\text { Model Chi-square }=55.675, \mathrm{p}=0.0001^{*}\right)\end{array}$} & $b_{o}$ & $?$ & -2.2374 & 12.3925 & $0.000 *$ & \\
\hline & $b_{1}$ & + & 0.9091 & 14.2705 & $0.000 *$ & 2.482 \\
\hline & $\mathrm{b}_{2}$ & + & -0.1650 & 0.7327 & 0.196 & 0.848 \\
\hline & $\mathrm{b}_{3}$ & + & 2.9642 & 9.9273 & $0.001 *$ & 19.380 \\
\hline & $\mathrm{b}_{4}$ & + & 15.9231 & 24.6821 & $0.000 *$ & 999.000 \\
\hline & $b_{5}$ & + & 0.8476 & 0.2282 & 0.316 & 2.334 \\
\hline
\end{tabular}


Table 8(cont'd)

Association Between Absolute Value of Discretionary Accruals and Audit Qualification with Controls Excluding 2-digit SIC Code 49

$($ Qualified $=115$, Unqualified $=115)$

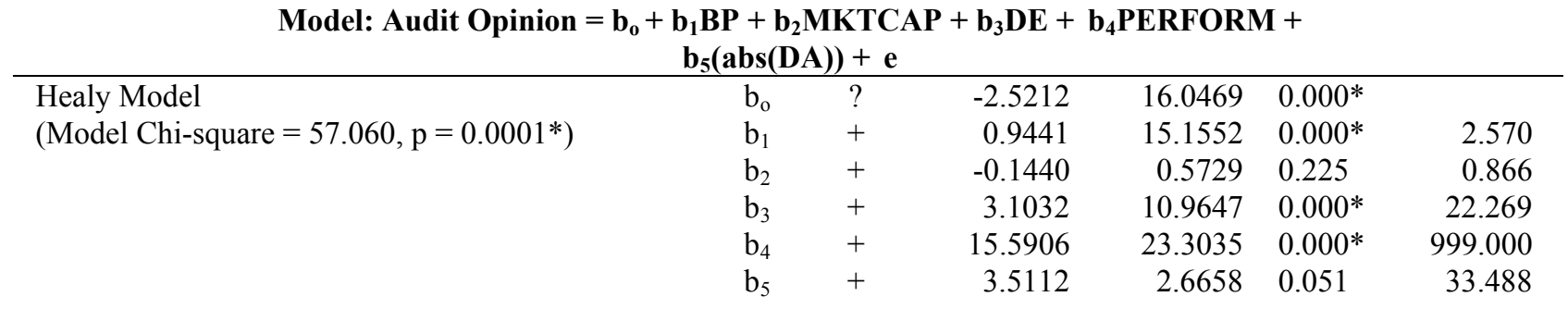

* $\mathrm{p} \leq 0.01$ (one-tailed tests for the slopes, two-tailed tests for the intercepts and the models).

$* * \mathrm{p} \leq 0.05$ (one-tailed tests for the slopes, two-tailed tests for the intercepts and the models).

The chi-square probabilities are for one-tailed tests for the slopes and two-tailed tests for the intercepts and the models.

Audit Opinion is a dummy variable set to 0 for unqualified audit report and to 1 for qualified report.

DA is discretionary accruals as of fiscal year end of the event year.

$\mathrm{BP}$ is book-to-market ratio as of fiscal year end of the event year.

MKTCAP is log base 10 of market capitalization as of fiscal year end of the event year.

$\mathrm{DE}$ is long-term debt-to-total asset ratio.

PERFORM is the absolute change in income from continuing operations in the event year divided by the total assets of the previous fiscal year end. 
Table 9

Association Between Absolute Value of Discretionary Accruals and

Audit Qualification with Controls

$($ Qualified $=166$, Unqualified $=166)$

Audit Opinion $=b_{0}+b_{1} B P+b_{2}$ MKTCAP $+b_{3}$ DE $+b_{4}$ PERFORM $+b_{5}(\operatorname{abs}(D A))+b_{6} B I G 6 *(\operatorname{abs}($ DA $\left.))\right)+e$

Jones Model

$\left(\right.$ Model Chi-square $\left.=66.885, \mathrm{p}=0.0001^{*}\right)$

Modified-Jones Model

$\left(\right.$ Model Chi-square $\left.=66.736, p=0.0001^{*}\right)$

Cross-sectional Jones Model

(Model Chi-square $=70.331, \mathrm{p}=0.0001^{*}$ )

Cross-sectional Modified-Jones Model

$\left(\right.$ Model Chi-square $=69.118, \mathrm{p}=0.0001^{*}$ )

Industry Model

(Model Chi-square $=68.064, \mathrm{p}=0.0001^{*}$ )

\begin{tabular}{|c|c|c|c|c|}
\hline $\begin{array}{l}\text { Expected } \\
\text { Sign }\end{array}$ & Coeff. & $\begin{array}{l}\text { Chi- } \\
\text { square }\end{array}$ & Prob. & $\begin{array}{l}\text { Odds } \\
\text { Ratio }\end{array}$ \\
\hline$?$ & -2.6017 & 21.5464 & $0.000 *$ & \\
\hline+ & 1.1025 & 22.2879 & $0.000 *$ & 3.012 \\
\hline+ & -0.1121 & 0.5170 & 0.236 & 0.894 \\
\hline+ & 3.8190 & 19.1870 & $0.000 *$ & 45.560 \\
\hline+ & 15.0028 & 24.2909 & $0.000 *$ & 999.000 \\
\hline+ & 2.0577 & 1.0318 & 0.155 & 7.828 \\
\hline- & -1.4052 & 0.1967 & 0.329 & 0.245 \\
\hline$?$ & -2.6164 & 21.7656 & $0.000 *$ & \\
\hline+ & 1.0978 & 22.1960 & $0.000 *$ & 2.998 \\
\hline+ & -0.1041 & 0.4464 & 0.252 & 0.901 \\
\hline+ & 3.8138 & 19.2049 & $0.000 *$ & 45.322 \\
\hline+ & 15.1477 & 24.7362 & $0.000 *$ & 999.000 \\
\hline+ & 1.8335 & 0.8582 & 0.177 & 6.256 \\
\hline- & -0.4693 & 0.0238 & 0.439 & 0.625 \\
\hline$?$ & -2.9580 & 26.6334 & $0.000 *$ & \\
\hline+ & 1.1339 & 23.0093 & $0.000^{*}$ & 3.108 \\
\hline+ & -0.0556 & 0.1262 & 0.361 & 0.946 \\
\hline+ & 4.0731 & 21.0824 & $0.000 *$ & 58.741 \\
\hline+ & 14.4868 & 22.8093 & $0.000 *$ & 999.000 \\
\hline+ & 5.0191 & 5.0175 & $0.013 * *$ & 151.273 \\
\hline- & -1.0366 & 0.0949 & 0.379 & 0.355 \\
\hline$?$ & -2.8656 & 25.3633 & $0.000 *$ & \\
\hline+ & 1.1295 & 22.8729 & $0.000 *$ & 3.094 \\
\hline+ & -0.0717 & 0.2115 & 0.323 & 0.931 \\
\hline+ & 4.0112 & 20.5901 & $0.000 *$ & 55.213 \\
\hline+ & 14.6467 & 23.2933 & $0.000 *$ & 999.000 \\
\hline+ & 4.1128 & 3.6345 & $0.028 * *$ & 61.118 \\
\hline- & -0.9967 & 0.0974 & 0.377 & 0.369 \\
\hline$?$ & -2.7820 & 23.6652 & $0.000 *$ & \\
\hline+ & 1.1193 & 22.8438 & $0.000 *$ & 3.063 \\
\hline+ & -0.0876 & 0.3160 & 0.287 & 0.916 \\
\hline+ & 3.9862 & 20.3102 & $0.000 *$ & 51.852 \\
\hline+ & 14.6686 & 23.2784 & $0.000 *$ & 999.000 \\
\hline+ & 3.1252 & 2.6821 & 0.051 & 22.764 \\
\hline- & -1.2983 & 0.2079 & 0.324 & 0.273 \\
\hline
\end{tabular}


Table 9 (cont'd)

Association Between Absolute Value of Discretionary Accruals and

Audit Qualification with Controls

$($ Qualified $=166$, Unqualified $=166)$

\begin{abstract}
Audit Opinion $=b_{0}+b_{1} B P+b_{2}$ MKTCAP $+b_{3}$ DE $+b_{4}$ PERFORM $+b_{5}(\operatorname{abs}($ DA $))+b_{6}$ BIG6*(abs $($ DA $\left.\left.)\right)\right)+e$
\end{abstract}

\begin{tabular}{|c|c|c|c|c|c|c|}
\hline & & $\begin{array}{l}\text { Expected } \\
\text { Sign }\end{array}$ & Coeff. & $\begin{array}{l}\text { Chi- } \\
\text { square }\end{array}$ & Prob. & $\begin{array}{l}\text { Odds } \\
\text { Ratio }\end{array}$ \\
\hline DeAngelo Model & $b_{o}$ & $?$ & -2.4670 & 18.1179 & $0.000^{*}$ & \\
\hline \multirow[t]{6}{*}{$\left(\right.$ Model Chi-square $\left.=67.480, p=0.0001^{*}\right)$} & $b_{1}$ & + & 1.1070 & 21.8323 & $0.000 *$ & 3.025 \\
\hline & $\mathrm{b}_{2}$ & + & -0.1540 & 0.9499 & 0.165 & 0.857 \\
\hline & $b_{3}$ & + & 3.8316 & 18.4269 & $0.000 *$ & 46.137 \\
\hline & $b_{4}$ & + & 15.5158 & 25.6204 & $0.000 *$ & 999.000 \\
\hline & $b_{5}$ & + & 1.2814 & 0.4749 & 0.245 & 3.602 \\
\hline & $\mathrm{b}_{6}$ & - & -3.7090 & 1.8556 & 0.087 & 0.025 \\
\hline Healy Model & $b_{o}$ & $?$ & -2.6999 & 22.2806 & $0.000^{*}$ & \\
\hline \multirow[t]{6}{*}{$($ Model Chi-square $=66.930, \mathrm{p}=0.0001 *)$} & $b_{1}$ & + & 1.1114 & 22.3230 & $0.000 *$ & 3.039 \\
\hline & $\mathrm{b}_{2}$ & + & -0.0965 & 0.3835 & 0.268 & 0.908 \\
\hline & $b_{3}$ & + & 3.9265 & 19.6079 & $0.000 *$ & 50.728 \\
\hline & $\mathrm{b}_{4}$ & + & 14.9395 & 24.0770 & $0.000^{*}$ & 999.000 \\
\hline & $b_{5}$ & + & 2.6041 & 1.3211 & 0.125 & 13.520 \\
\hline & $b_{6}$ & - & -0.5815 & 0.0318 & 0.429 & 0.559 \\
\hline
\end{tabular}

* $\mathrm{p} \leq 0.01$ (one-tailed tests for the slopes, two-tailed tests for the intercepts and the models).

$* * \mathrm{p} \leq 0.05$ (one-tailed tests for the slopes, two-tailed tests for the intercepts and the models).

The chi-square probabilities are for one-tailed tests for the slopes and two-tailed tests for the intercepts.

Audit Opinion is a dummy variable set to 0 for unqualified audit report and to 1 for qualified report.

DA is discretionary accruals as of fiscal year end of the event year.

BP is book-to-market ratio as of fiscal year end of the event year.

MKTCAP is log base 10 of market capitalization as of fiscal year end of the event year.

$\mathrm{DE}$ is long-term debt-to-total asset ratio.

PERFORM is the absolute change in income from continuing operations in the event year divided by the total assets of the previous fiscal year end.

BIG6 equals 0 if Big Six auditor ( $n=144), 1$ if non-Big Six auditor $(n=22)$. 